\title{
Production performance and meat quality of local ducks fed rations containing extract of torch ginger (Etlingera elatior) flowers and betel (Piper Betle linn) leaves
}

\author{
Ristika Handarini*, Elis Dihansih, Dewi Wahyuni and Burhanudin Malik \\ Department of Animal Husbandry, Faculty of Agriculture, Djuanda University, Bogor 16720
}

Submitted: 29 April 2020, Accepted: 06 June 2021

\begin{abstract}
Compared to chickens, ducks still have low productivity and other limitations. One of the causes of these problems might be attributed to the off-odor found in duck meat. Therefore, production performance and meat quality of ducks need to be improved. The inclusion of extracts of betel (Piper betle Linn) leaves and torch ginger (Etlingera elatior) flowers wereas done to improve production performance and meat quality of local ducks. This study was aimed at assessing the effects of the inclusion of betel leaves and torch ginger flowers in the basal rations on production performance and meat quality of local ducks in the growing phase. A completely randomized factorial design in $4 \times 4$ with three replicates was used. The first factor consisted of four levels of torch ginger flower solution, namely $0,2.5,5$, and $7.5 \%$. The second factor consisted of four levels of betel leaf solution, namely $0,2.5,5$, and $7.5 \%$. Results showed that no significant differences $(\mathrm{P}>0.05)$ were found in body weight gain, feed intake, feed conversion, mortality rate and meat quality $(\mathrm{pH}$, water holding capacity, tenderness and cooking loss). It was concluded that the inclusion of extract of betel leaves and torch ginger flowers did not improve production performance and meat quality of male local ducks.
\end{abstract}

Keywords: Herb; Antioxidant; Feed conversion; Meat off-odor

\footnotetext{
*Corresponding Author: ristika.handarini@unida.ac.id
} 


\section{INTRODUCTION}

Duck is one of local poultry available to provide meat and egg for consumers. However, the productivity level of local duck is much lower than that of chicken. In addition, duck meat is found to be less preferred as it has off-odor, darker color, coarser texture, and tougher than chicken meat (Ali et al., 2007). Therefore, efforts need to be done in order to improve duck production performance and meat quality with a special attention on the elimination of its meat off-odor.

Yet, today, especially in developed countries where public health is a big concern, the use of antibiotics is restricted or even banned..(Islam et al., 2014) Several herbs such as green tea (Biswas \& Wakita, 2001), oregano (Park et al., 2015) ,sea tangle(Islam et al., 2014), roosbos tea (Juráni et al., 2008), and (Indian camphorweed (Rukmiasih, 2011) were attempted to be used as natural antibiotics, growth promoters, antimicrobial agents, or antioxidants. Betel leaves and torch ginger flowers therefore might be used as feed additives. Betel leaf extract is found to have antibacterial and antioxidant activities. It was found enable to kill decomposing and pathogenic bacteria including $E$. coli. The use of betel leaf extract, compared to zinc bacitracin, was shown to potentially improve nitrogen retention and metabolizable energy of broiler rations (Sudrajat \& Kardaya, 2017). Similarly, the flowers, stems, rhizomes, and leaves of torch ginger contains alkcaloid, saponin, tannin, phenolic, flavonoid, triterpenoid, steroid, and glycoside compounds which can actively play a role as antioxidants (Naufalin et al., 2005). The main chemical components contained in torch ginger flower are 1-dodecanol (13.82\%), dodecanal (12.1\%), and 17-pentatriacontane (10.52\%). Torch ginger flowers extracted in methanol were found to have higher antioxidant potential (IC $50=21.14 \mathrm{ug} / \mathrm{ml}$ ) than those extracted in ethyl acetate (IC 50 = 68.24 $\mathrm{ug} / \mathrm{ml}$ against $\mathrm{DPPH}$ free
radicals(Maimulyanti \& Prihadi, 2015). The inclusion of 0.5 and $1.0 \%$ of dried oregano powder in rations were found to improve meat cooking loss, reduce TBARS values, and increase GPx and SOD activities of meat in ducks (Park et al., 2015). Proportion of leg muscle was higher, but abdominal fat was lower, and meat color was improved, as well as Lactobacillus growth was higher in broiler chickens fed diets containing green tea powder (Juráni et al., 2008).

\section{MATERIALS AND METHODS}

The study was conducted for two months at the Duck Farm of Department of Animal Science, Faculty of Agriculture, Djuanda University, Bogor. One-hundredand-forty-four male local ducks aged 2 weeks were used.

Extract of torch ginger flowers and betel leaves were prepared in the following way: 1) a liter of water was added to $600 \mathrm{~g}$ of mashed betel leaves/torch ginger flowers; - 2). The mixture was boiled at $60^{\circ} \mathrm{C}$ for 30 minutes, - 3) the boiled mixture was then sieved to obtain betel leaf/torch ginger flower extract, - 4) the extract was then cooled and stored at $4^{\circ} \mathrm{C}$. Betel leaf and torch ginger flower extract solution obtained was used into duck rations treatments.

Commercial ration (Genta GT-10) of PT Sinta Prima Feedmill containing $10.02 \%$ water, $5.11 \%$ ash, $4.72 \%$ fat, $20.06 \%$ protein, and $3.14 \%$ fiber for broiler finisher was used as a basal ration. A completely randomized design in $4 \mathrm{x} 4$ factorial scheme was used. The first factor consisted of four levels of torch ginger flower solution (TGFS) and the second factor consisted of four levels of betel leaf solution (BLS). Each treatment had 3 replicates consisting of 3 ducks each. The treatments were as follows:

$\begin{array}{lll}\text { R1 } & \text { : BLS 0 } \% & \text { + TGFS 0 } \\ \text { R2 } & \text { : BLS 2,5 } \% & \text { + TGFS 0\% } \\ \text { R3 } & \text { : BLS 5 } \% & \text { + TGFS } 0 \% \\ \text { R4 } & \text { : BLS 7.5\% } & \text { + TGFS 0 } \% \\ \text { R5 } & \text { : BLS 0 } \% & \text { + TGFS } 2.5 \%\end{array}$




\begin{tabular}{|c|c|c|}
\hline R6 & BLS $2.5 \%$ & + TGFS $2.5 \%$ \\
\hline R7 & : BLS $5 \%$ & + TGFS $2.5 \%$ \\
\hline $\mathrm{R} 8$ & BLS $7.5 \%$ & + TGFS $2.5 \%$ \\
\hline R9 & : BLS $0 \%$ & + TGFS $5 \%$ \\
\hline R10 & : BLS $2.5 \%$ & + TGFS $5 \%$ \\
\hline $\mathrm{R} 11$ & : BLS $5 \%$ & + TGFS $5 \%$ \\
\hline $\mathrm{R} 12$ & : BLS $7.5 \%$ & + TGFS $5 \%$ \\
\hline $\mathrm{R} 13$ & : BLS $0 \%$ & + TGFS $7.5 \%$ \\
\hline R14 & : BLS $2.5 \%$ & + TGFS $7.5 \%$ \\
\hline $\mathrm{R} 15$ & BLS $5 \%$ & + TGFS $7.5 \%$ \\
\hline $\mathrm{R} 16$ & BLS $7.5 \%$ & + TGFS $7.5 \%$ \\
\hline
\end{tabular}

Measurements were taken on feed intake, final body weight, body weight gain, feed conversion, mortality rate, and meat quality parameters including $\mathrm{pH}$, water holding capacity, tenderness, and cooking loss.

\section{RESULT AND DISCUSSION}

Average feed intake, feed conversion, and body weight gain of male local ducks aged 4-10 weeks were listed in Table 1.

\section{Feed Intake}

Average feed intake of male local ducks aged 4-10 weeks were 3869.3 to $4157.1 \mathrm{~g} /$ duck. No different feed intake was found indicating that the inclusion of betel leaf and torch ginger flower solution in ration did not change feed intake. In other words, the inclusion of betel leaf and torch ginger flower solution by up to $7.5 \%$ each did not affect palatability in ducks. As a comparison, feed intake in this study was lower than that (4499.73-4508.79 g/duck) obtained by(Widianto et al., 2015) in ducks fed great morinda meal for 40 days. Feeding the ducks for 10 weeks (Iskandar et al., 2001) found that two-week old ducks which were raised until they were 10 weeks old had a feed intake of $7500 \mathrm{~g} / \mathrm{duck}$ while that of (Purba 2010) was 7242.14-7635.72 g/duck within 8 weeks.

\section{Body Weight Gain}

Results showed that the body weight gain of male local ducks reared from the age of 4-10 weeks was 889.1-1095 g. No differences in body weight gain were found. This result was in line with that of (Park et al., 2015) who added oregano meal as antioxidants into the rations of Cherry Valley ducks. The inclusion of torch ginger with and without betel leaves in rations did not increase body weight gain. This might due to the fact that the ducks were reared intensively in clean individual cages and had a similar feed intake. Active substances contained in betel leaves and torch ginger flowers did not seem to function as antibiotics or growth promoters.

Table 1. Average body weight gain, feed intake, and feed conversion of male local ducks aged 4-10 weeks

\begin{tabular}{lccccc}
\hline \multirow{2}{*}{ Parameter } & \multicolumn{5}{c}{ Treatment } \\
\cline { 2 - 6 } & $\begin{array}{c}\text { Betel Leaf } \\
\text { Extract }(\%)\end{array}$ & 0 & 2.5 & 5 & 7.5 \\
\hline Body & 0 & $1075 \pm 30$ & $1083 . \pm 135$ & $889.1 \pm 28.9$ & $1091.6 \pm 170$ \\
Weight gain & 2.5 & $955 \pm 105$ & $1011.6 \pm 53$ & $1005 \pm 154$ & $1033.3 \pm 142$ \\
(g) & 5 & $968.3 \pm 118$ & $1048 \pm 115$ & $1050 \pm 134$ & $941.6 \pm 118$ \\
& 7.5 & $946.6 \pm 120$ & $1095 \pm 66$ & $1016 \pm 76$ & $985 \pm 59$ \\
Feed Intake & 0 & $4141 \pm 111$ & $4068 \pm 104$ & $3869.3 \pm 363$ & $4071.3 \pm 124$ \\
(g) & 2.5 & $4151.2 \pm 32$ & $4112.9 \pm 19$ & $4113.1 \pm 51$ & $4138.1 \pm 80$ \\
& 5 & $4151.1 \pm 11$ & $4157.1 \pm 20$ & $4113.4 \pm 51$ & $4117.4 \pm 51$ \\
Feed & 7.5 & $4136.5 \pm 54$ & $4147.3 \pm 16$ & $4115.6 \pm 46$ & $4151.8 \pm 16$ \\
Conversion & 0 & $3.85 \pm 0.03$ & $3.79 \pm 0.51$ & $4.35 \pm 0.40$ & $3.78 \pm 0.53$ \\
& 2.5 & $4.38 \pm 0.50$ & $4.07 \pm 0.23$ & $4.15 \pm 0.64$ & $4.06 \pm 0.64$ \\
& 5 & $4.32 \pm 0.48$ & $4.00 \pm 0.49$ & $3.96 \pm 0.50$ & $4.42 \pm 0.58$ \\
\hline
\end{tabular}

Note: no significant differences were detected $(\mathrm{P}>0.05)$ 


\section{Feed Conversion}

The feed conversion of male local ducks reared from the age of 4-10 weeks was 3.78-4.41. No differences in feed conversion were found. This might be attributed to no differences in feed intake and body weight gain. However, the feed conversion found in this study was lower than that $(5.35 \pm 0.25)$ found by (Purba 2010) in MA ducks given santoquin and vitamin E supplementation.

\section{Mortality Rate}

During the trial period done from the age of 4 to 10 weeks, no duck was found died, so the mortality rate of was $0 \%$. This showed that the inclusion of extract of betel leaves and torch ginger flowers substances having antimicrobial property (Maimulyanti \& Prihadi, 2015) and (Sudrajat \& Kardaya, 2017) might partly explain the finding in this study.

Table 2. Average meat quality of male local ducks aged 10 weeks

\begin{tabular}{lccccc}
\hline \multirow{2}{*}{ Parameters } & \multicolumn{5}{c}{ Treatments } \\
\cline { 2 - 6 } & $\begin{array}{c}\text { Betel Leaf } \\
\text { Extract }(\%)\end{array}$ & 0 & \multicolumn{4}{c}{ Torch Ginger Flower Extract $(\%)$} \\
\hline $\mathrm{pH}$ & 0 & $5.97 \pm 0.06$ & $5.90 \pm 0.10$ & $5.97 \pm 0.02$ & $5.84 \pm 0.04$ \\
& 2.5 & $5.87 \pm 0.06$ & $6.08 \pm 0.07$ & $5.84 \pm 0.04$ & $5.88 \pm 0.07$ \\
& 5 & $5.96 \pm 0.03$ & $5.87 \pm 0.06$ & $6.02 \pm 0.04$ & $5.91 \pm 0.02$ \\
& 7.5 & $6.03 \pm 0.04$ & $6.07 \pm 0.12$ & $6.01 \pm 0.02$ & $5.93 \pm 0.03$ \\
\hline Water & 0 & $48.10 \pm 1.15$ & $48.13 \pm 0.32$ & $48.0 \pm 0.44$ & $52.19 \pm 0.22$ \\
holding & 2.5 & $48.27 \pm 0.06$ & $49.64 \pm 0.55$ & $47.07 \pm 0.5$ & $50.73 \pm 0.23$ \\
capacity (\%) & 5 & $52.27 \pm 0.25$ & $47.33 \pm 0.64$ & $46.78 \pm 1.2$ & $52.79 \pm 0.11$ \\
& 7.5 & $48.17 \pm 0.74$ & $47.43 \pm 0.70$ & $47.18 \pm 0.2$ & $45.60 \pm 0.52$ \\
\hline Tenderness & 0 & $4.11 \pm 0.34$ & $4.12 \pm 0.39$ & $3.96 \pm 0.11$ & $3.59 \pm 0.18$ \\
$\left(\right.$ kg/cm $\left.{ }^{2}\right)$ & 2.5 & $3.87 \pm 0.37$ & $4.13 \pm 0.27$ & $4.37 \pm 0.16$ & $3.82 \pm 0.17$ \\
& 5 & $3.71 \pm 0.20$ & $3.92 \pm 0.26$ & $3.92 \pm 0.25$ & $3.74 \pm 0.16$ \\
& 7.5 & $3.95 \pm 0.20$ & $3.77 \pm 0.21$ & 3.790 .25 & $3.91 \pm 0.37$ \\
\hline Cooking loss & 0 & $40.57 \pm 3.09$ & $42.1 \pm 7.57$ & $36.03 \pm 2.2$ & $41.6 \pm 2.15$ \\
$(\%)$ & 2.5 & $46.45 \pm 2.45$ & $41.58 \pm 4.64$ & 39.033 .1 & $38.49 \pm 1.88$ \\
& 5 & $43.9 \pm 3.78$ & $43.84 \pm 2.78$ & $46.6 \pm 2.4$ & $44.51 \pm 1.96$ \\
& 7.5 & $42.87 \pm 2.67$ & $39.48 \pm 0.78$ & $45.49 \pm 4.9$ & $41.8 \pm 2.75$ \\
\hline
\end{tabular}

Note: no significant differences were detected $(\mathrm{P}>0.05)$

\section{Meat Quality}

Meat $\mathrm{pH}$ of local ducks fed extract of torch ginger flower and betel leaves was not significant $(\mathrm{P}>0.05)$. The range of meat $\mathrm{pH}$ resulted from this study was 5.84 to 6.08 . These figures were higher than those (5.905.96) of meat of Korean local ducks fed oregano powder (Park et al., 2015). Water holding capacity (45.60 to $52.79 \%$ ) of meat was also not significant $(\mathrm{P}>0.05)$. As comparison, water holding capacity of meat of Korean local ducks fed oregano powder as herb antioxidant was $48.17 \%$ (Park et al., 2015). Meat tenderness as tested by using a
Warner Blatzer method in ducks fed extract of betel leaves and torch ginger flowers was found to be not significant $(\mathrm{P}>0.05)$. It ranged from around 3.59 to $4.37 \mathrm{~kg} / \mathrm{cm}^{3}$. Meat with these tenderness levels was categorized as tender. Treatments, therefore, did not improve cooking loss which ranged from 36.03 to $46.60 \%$ ( $\mathrm{P}>0.05)$. These findings were in contrast with the results of a study carried out by (Park et al., 2015) who found that feeding antioxidant-rich herb supplement (oregano) significantly reduced cooking loss by about $50 \%$, from $15.17 \%$ to $7.71 \%$. 


\section{CONCLUSIONS}

The inclusion of extract of betel leaf and torch ginger flower solution in the rations did not affect production performance and meat quality in male local ducks.

\section{AKNOWLEDGEMENT}

Funding assistance under the Excellent Research Grant Scheme (Contract Number 105/SP2H/PPM/DRPM/II/2016) from the Ministry of Research, Technology, and Higher Education was acknowledged.

\section{REFERENCES}

Ali, M. S., Kang, G. H., Yang, H. S., Jeong, J. Y., Hwang, Y. H., Park, G. B., \& Joo, S. T. (2007). A comparison of meat characteristics between duck and chicken breast. Asian-Australasian Journal of Animal Sciences, 20(6), 1002-1006. https://doi.org/10.5713/ ajas.2007.1002

Biswas, M. A. H., \& Wakita, M. (2001). Effect of dietary japanese green tea powder supplementation on feed utilization and carcass profiles in broilers md . abdul hai biswas * and masaaki wakita faculty of bioresources, mie responses of broiler to dietary japanese green tea powder ( GTP) wer. Journal of Poultry Science, $38,50-57$.

Iskandar, S., Nugraha, vanvan S., M, D., Suci, \& Setioko, A. (2001). ZE3AK PADl TINGGF (Vol. 1).

Islam, M. M., Ahmed, S. T., Kim, Y. J., Mun, H. S., Kim, Y. J., \& Yang, C. J. (2014). Effect of sea tangle (laminaria japonica) and charcoal supplementation as alternatives to antibiotics on growth performance and meat quality of ducks. AsianAustralasian Journal of Animal Sciences, 27(2), 217-224. https://doi. org/10.5713/ajas.2013.13314

Juráni, M., Lamošsová, D., MáčAjová, M., Košt’ál, L., Joubert, E., \& Greksák, M. (2008). Effect of rooibos tea (Aspalathus linearis) on Japanese quail growth, egg production and plasma metabolites. British Poultry Science, 49(1), 55-64. https://doi.org/ 10.1080/00071660701816949

Maijon, P. 2010. "Penurunan Intensitas Off odor pada daging itik lokal dengan suplementasi Santoquin dan Vitamin E dalam Ransum.," Institut Pertanian Bogor. Bogor,.

Maimulyanti, A., \& Prihadi, A. R. (2015). Chemical composition, phytochemical and antioxidant activity from extract of Etlingera elatior flower from Indonesia. Journal of Pharmacognosy and Phytochemistry, 3(6), 233-238.

Naufalin, R., Soedirman, U. J., Sri, B., Jenie, L., \& Sudarwanto, M. (2005). Antibacterial activity of kecombrang flower extract toward pathogenic and food spoilage bacteria. Jurnal Teknologi Dan Industri Pangan, 16(2), 119-125.

Park, J. H., Kang, S. N., Shin, D., \& Shim, K. S. (2015). Antioxidant enzyme activity and meat quality of meat type ducks fed with dried oregano (Origanum vulgare L.) powder. AsianAustralasian Journal of Animal Sciences, 28(1), 79-85. https://doi. org/10.5713/ajas.14.0313

Rukmiasih. (2011). Penurunan bau amis (offodor) daging itik lokal dengan pemberian daun beluntas (Pluchea indica Less) dalam pakan dan dampaknya terhadap performa. Sekolah Pascasarjana Institut Pertanian Bogor.

Sudrajat, D., \& Kardaya, D. (2017). Pengaruh larutan daun sirih dalam air minum sebagai pengganti antibiotik terhadap retensi nitrogen dan energi metabolis ransum. Jurnal Peternakan Nusantara, 1(1), 33-40.

Widianto, B., Setyo Prayogi, H., \& Nuryadi, N. (2015). Pengaruh penambahan tepung buah mengkudu (Morinda citrifolia L.) dalam pakan terhadap penampilan produksi itik Hibrida. Jurnal Ilmu-Ilmu Peternakan, 25(2), 28-35. https://doi.org/10.21776/ub.ji ip.2015.025.02.04 